УДК 343.1

DOI https://doi.org/10.32837/pyuv.v0i2(27).214

\author{
В. І. Любченко \\ здобувач Університету сучасних знань, \\ завідувач Запорізького відділення \\ Дніпропетровського науково-дослідного інституту судових експертиз \\ Міністерства юстииї України
}

\title{
МІСЦЕ СЛІДЧОГО, КЕРІВНИКА ОРГАНУ ДОСУДОВОГО РОЗСЛІДУВАННЯ ТА СПІВРОБІТНИКА ОПЕРАТИВНОГО ПІДРОЗДІЛУ В РЕАЛІЗАЦЇ̈ ФУНКЦІЇ ОБВИНУВАЧЕННЯ В ІІЇ ПОЧАТКОВІЙ (ДОСУДОВІЙ) ФОРМІ
}

При прийнятті Кримінального процесуального кодексу Україні (далі - КПК України) 2012 р. вітчизняний законодавець безапеляційно зарахував слідчого (ст. 40 КПК України), керівника органу досудового розслідування (ст. 39 КПК України) і співробітника оперативного підрозділу (ст. 41 КПК України) до сторони обвинувачення. Це рішення законодавця посилило дискусію про місце означених владних суб'єктів досудового розслідування в системі кримінальної процесуальної діяльності та характер кримінальних процесуальних функцій, які вони мають виконувати. Більшість вітчизняних вчених-правознавців вкрай негативно сприймають цю новелу чинного КПК України.

Так, Н.I. Клименко, О.А. Баулін, В.М. Юрчишиин та інші наголошують, що слідчий не має бути ні обвинувачем, ні захисником, бо він є об'єктивним і неупередженим шукачем і дослідником істини по справі, у зв'язку з чим основною його кримінальною процесуальною функцією має бути лише функція розслідування кримінальних правопорушень $[1$, с. $20 ; 2$, с. $9-11 ; 3$, с. 97]. Ми ж не погоджуємося 3 доводами цих авторів і вважаємо, що діяльність слідчого, керівника органу досудового розслідування і співробітника оперативного підрозділу спрямована виключно на встановлення особи, яка вчинила кримінальне правопорушення з подальшим її викриттям у цьому правопорушенні. Це означає, що їх кримінальна процесуальна діяльність за своїм змістом має суто обвинувальний характер. Саме в досудовому розслідуванні здійснюється підготовка і формування обвинувачення в його початковій (досудовій) формі як «твердження про вчинення певною особою діяння, передбаченого Законом України про кримінальну відповідальність, висунуте в порядку, встановленому нормами КПК України» (п. 13 ч. 1 ст. 3 КПК України).

Якщо на основі зібраних у процесі розслідування доказів винуватість підозрюваного у вчиненні кримінального правопорушення підтвердиться повністю, слідчий складає обвинувальний акт і спрямовує його прокурору для вирішення питання про можливість його затвердження і ске- рування до суду (ст. 291 КПК України). Саме ці процесуальні дії і рішення слідчого зумовлюють беззаперечне зарахування його до сторони обвинувачення.

3 прийняттям КПК України 2012 р. суттєво змінився процесуальний порядок трансформації підозри в обвинувачення. Підозра - обов'язковий етап досудового розслідування. Вона має бути перевірена усією сукупністю зібраних доказів, виключаючими можливість їі спростування і лише при незаперечному пітвердженні трансформована в обвинувачення [4, с. 241]. Кримінальні процесуальні повноваження слідчого врегульовані ст. 40 КПК України. Крім розслідування кримінального правопорушення, його прямим обов'язком $\epsilon$ ще й активний розшук підозрюваного, який переховується від слідства і суду (ч. 1 ст. 281 КПК України). Здійснення розшуку підозрюваного слідчий має право доручити оперативному підрозділу (ч. 3 ст. 281 КПК України). Слідчий самостійно приймає процесуальні рішення, за винятком випадків, коли законом передбачено отримання попередньої згоди прокурора чи слідчого судді.

Все це означає, що діяльність слідчого, пов'язана з виявленням доказів для підозри певної особи у вчинення кримінального правопорушення, обгрунтуванням підозри, встановленням підстав для застосування до підозрюваного процесуальних заходів забезпечення кримінального провадження, викриттям підозрюваного у вчиненні кримінального правопорушення, за своїм характером і змістом є обвинувальною, що обгрунтовано зараховано законодавцем до сторони обвинувачення, очолюваної прокурором. Особливий наголос ставимо на тому, що саме слідчий безпосередньо формує основний масив обвинувальних доказів та їх процесуальні джерела. Процесуальний механізм викриття підозрюваного у вчиненні кримінального правопорушення теж знаходить своє відображення в обгрунтованих і вмотивованих рішеннях слідчого обвинувального характеру [5, с. 51-54]. Отже, дослідження обвинувальної діяльності слідчого має важливе теоретичне і практичне значення, бо підозрюваний, а потім і обвинувачений з'являються у кримінальному провадженні в ре- 
зультаті копіткої, об’ємної і складної матеріально-пошукової роботи слідчого. Правильно зазначає Р. Савонюк, що право слідчого на висунення обвинувачення у його початковій (досудовій) формі є невід'ємним від слідчої діяльності [6, с. 73]. Отже, зміни, які відбулися в обвинувально-слідчій діяльності за КПК України 2012 р., мають конструктивний характер. Якщо початкова (досудова) форма обвинувачення є підготовчою і нею займаються всі владні суб'єкти досудового розслідування (крім слідчого судді), то навіщо структурним і процесуальним обособленням слідчого від прокурора руйнувати єдність учасників обвинувачення і тим самим цілеспрямовано послаблювати функцію обвинувачення. Наявність на стороні обвинувачення незалежних один від одного слідчого і прокурора ніколи не дає позитивних результатів ані у конкурентній боротьбі зі стороною захисту, ані з криміналітетом.

Керівник органу досудового розслідування (ст. 39 КПК України) також обгрунтовано зарахований законодавцем до сторони обвинувачення, бо коло наданих йому повноважень дає йому змогу, з одного боку, здійснювати організацію досудового розслідування, а з іншого - брати активну участь на стороні обвинувачення, бо він має пряме відношення як до забезпечення швидкого і повного розкриття кримінальних правопорушень, так і до викриття осіб, які їх вчинили. Усі процесуальні повноваження цього владного суб'єкта досудового розслідування, визначені ст. 39 КПК України, носять обвинувальну спрямованість. Крім того, обвинувальний характер діяльності керівника органу досудового розслідування визначається ще й його безпосередньою близькістю до повсякденного об'єкта контролю - дій і рішеннь, які виконуються та приймаються підпорядкованими йому слідчими [7, с. 16].

Співробітники оперативних підрозділів, визначених ст. 41 КПК України, правоохоронних органів держави, які за письмовими дорученнями слідчих і прокурорів виконують окремі слідчі (розшукові) дії, також обгрунтовано зараховані законодавцем до сторони обвинувачення, бо специфіка їхніх процесуальних правовідносин із прокурорами і слідчими та характер процесуальних повноважень під час виконання письмових доручень свідчать про обвинувальну напрвленість їхніх процесуальних дій. Звичайно, нині щодо обвинувальної діяльності співробітників оперативних підрозділів є багато дискусійних проблем, що вимагають їх вирішення як на теоретичному, так і законодавчому рівнях.

\section{Jimepamypa}

1. Клименко Н.І. Закріплення у КПК України принципу змагальності і незалежності судових експертів. Юридичний часопис Національної акаделї̈ внутрішніх справ. 2013. № 1 (5). С. 19-23.
2. Попович I.M. Процесуальне положення сторін у досудовому розслідуванні: теоретичні, законодавчі та функціональні аспекти : автореф. дис. ... канд. юрид. наук : 12.00.09. Харків, 2019. 20 с.

3. Юрчишин В.М. Місце і роль прокурора у досудовому розслідуванні та їх відображення в теорії, законодавстві і практиці : монографія. Чернівці : Видавничий дім «Родовід», 2013. 308 с.

4. Капліна О.В. Підозра у кримінальному провадженні: поняття, ознаки, сутність. Юридичний часопис Національної акаделії внутрішніх справ. 2013. № 1 (5). С. 238-242.

5. Удовенко Ж. Забезпечення процесу доказування на досудовому слідстві: окремі проблеми. Право України. 2002. № 5. С. 51-54.

6. Савонюк Р. Кримінально-процесуальна функція та її зміст в діяльності слідчого як суб'єкта доказування. Право Украӥни. 2001. № 2. С. 69-73.

7. Семенцов В.А. Концептуальные основы системы следственных действий в досудебном производстве : автореф. дис. ... докт. юрид. наук : 12.00.09. Екатеринбург, 2006. 42 c.

\section{Анотація}

Любченко В. І. Місце слідчого, керівника органу досудового розслідування та співробітника оперативного підрозділу в реалізації функції обвинувачення в їі початковій (досудовій) формі. - Стаття.

На базі аналізу процесуального статусу слідчого, керівника органу досудового розслідування і співробітника оперативного підрозділу обгрунтовується обов'язкова участь цих владних суб'єктів досудового розслідування на стороні обвинувачення під час реалізації процесуальної функції обвинувачення в її початковій (досудовій) формі. Визначено, що діяльність слідчого, керівника органу досудового розслідування і співробітника оперативного підрозділу спрямована виключно на встановлення особи, яка вчинила кримінальне правопорушення з послідуючим її викриттям у цьому правопорушенні, тобто їх кримінальна процесуальна діяльність за своїм змістом має суто обвинувальний характер. Доведено, що діяльність слідчого, пов'язана з виявленням доказів для підозри певної особи у вчиненні кримінального правопорушення, обгрунтуванням підозри, встановленням підстав для застосування до підозрюваного процесуальних заходів забезпечення кримінального провадження, викриттям підозрюваного у вчиненні кримінального правопорушення, за своїм характером і змістом є обвинувальною і він обгрунтовано зарахований законодавцем до сторони обвинувачення, очолюваної прокурором. Наголошено, що керівник органу досудового розслідування обгрунтовано зарахований законодавцем до сторони обвинувачення, бо коло наданих йому повноважень дає йому змогу, з одного боку, здійснювати організацію досудового розслідування, а з іншого - брати активну участь на стороні обвинувачення, бо він має пряме відношення як до забезпечення швидкого і повного розкриття кримінальних правопорушень, так і до викриття осіб, які їх вчинили. 3'ясовано, що співробітники оперативних підрозділів, визначених ст. 41 КПК України, правоохоронних органів держави також обгрунтовано зараховані законодавцем до сторони обвинувачення, бо специфіка їхніх процесуальних правовідносин з прокурорами і слідчими та характер процесуальних повноважень під час виконання письмових доручень свідчать про обвинувальну направленість їхніх процесуальних дій. Зроблено висновок, що на сьогодні стосовно обвинувальної діяльності співробітників оперативних під- 
розділів є багато дискусійних проблем, що вимагають ïx вирішення як на теоретичному, так і законодавчому рівнях.

Ключові слова: кримінальне провадження, досудове розслідування, обвинувачення, сторона обвинувачення, слідчий, керівник органу досудового розслідування, співробітник оперативного підрозділу.

\section{Summary}

Liubchenko V.I. Place of investigator, head of pre-trial investigation body and officer of operational unit in exercising the charge function in its initial (pre-trial) form. - Article.

On the basis of the analysis of the procedural status of the investigator, the head of the pre-trial investigation body and the employee of the operational unit, the obligatory participation of these powerful subjects of pre-trial investigation on the side of the prosecution is substantiated during the implementation of the procedural function of the prosecution in its initial (pre-trial) form. It is determined that the activity of the investigator, the head of the pre-trial investigation body and the employee of the operational unit is aimed solely at identifying the person who committed the criminal offense with its subsequent exposure in this offense, that is, their criminal procedural activity is purely indictable. It is proved that the activity of the investigator, connected with the detection of evidence for suspicion of a certain person in the commission of a criminal offense, the justification of the suspicion, establishing the grounds for applying to the suspect procedural measures to secure criminal proceedings, exposing the suspect in committing a criminal offense, and it is reasonably attributed by the legislature to the prosecution led by the prosecutor. It is emphasized that the head of the pre-trial investigation body is reasonably attributed to the prosecution by the legislator, because the range of powers given to him allows him to organize pre-trial investigation on the one hand, and on the other to take an active part on the side of the prosecution, because he is directly related to ensuring rapid full disclosure of the criminal offenses, as well as the exposure of the perpetrators. It is found that the employees of the operational units defined by Art. 41 of the CPC of Ukraine's law enforcement agencies are also reasonably attributed to the prosecution by the legislator, since the specifics of their procedural relations with prosecutors and investigators and the nature of the procedural powers when executing written orders indicate the accusative nature of their proceedings. It is concluded that today there are many debates concerning the indictment of the employees of the operational units, which require their solving at both theoretical and legislative levels.

Key words: criminal proceedings, pre-trial investigation, prosecution, prosecution, investigator, head of the pre-trial investigation body, officer of the operational unit. 